\title{
EXTENDED CONTENTS
}

About the author

Preface

Acknowledgements

viii

List of abbreviations

ix

Table of cases

xiii

Table of legislation

xiv

xvii

xxii

\section{PART I THE BUSINESS OF CREDIT RATING}

1. THE CREDIT RATING INDUSTRY

A. INTRODUCTION

$\begin{array}{ll}\text { 1. The 'gatekeeper' function } & 1.07\end{array}$

2. Role of CRAs in the financial markets $\quad 1.17$

3. The reputational capital of CRAs $\quad 1.30$

$\begin{array}{ll}\text { 4. Structure of the book } & 1.53\end{array}$

2. BUSINESS MODEL OF CRAS

A. RATING METHODOLOGIES $\quad 2.01$

1. The bond rating services $\quad 2.09$

2. Solicited and unsolicited ratings $\quad 2.18$

B. CONFLICTS OF INTEREST $\quad 2.26$

1. Issues of the 'issuer-pays' business model 2.37

2. The over-reliance on CRA ratings $\quad 2.41$

C. THE DISCLOSURE REGIME $\quad 2.57$

1. The quest for accuracy of rating $\quad 2.62$

2. The impact of rating on sovereign debt $\quad 2.68$

D. COMPETITION IN THE RATINGS INDUSTRY 2.78

E. THE USE OF 'RATING TRIGGERS' IN FINANCIAL TRANSACTIONS

1. Procyclicality effect of rating triggers $\quad 2.90$

\section{PART II THE REGULATION OF CRAs}

3. GLOBAL REGULATORY FRAMEWORK

A. THE INTERNATIONAL APPROACH: THE IOSCO CODE 3.01

1. The soft law approach of the IOSCO Code 3.08

B. THE EXTERNAL CREDIT ASSESSMENT INSTITUTION

4. THE US REGIME

A. THE NATIONALLY RECOGNIZED STATISTICAL RATING ORGANIZATION

1. US regulation of CRAs $\quad 4.12$

5. THE EU REGIME

A. THE EUROPEAN REGULATORY RESPONSE $\quad 5.01$

1. Supervision of CRAs $\quad 5.06$

2. The role of ESMA $\quad 5.14$

6. THE UK REGIME
A. UK REGIME OF CRAs
1. The principles-based regime
B. PROPOSAL FOR AN EU CRA 


\section{PART III LIABILITY OF CRAs}

7. UNITED KINGDOM
A. PRELIMINARY CONSIDERATIONS
7.01
1. Liability in tort for economic loss
2. The tort of negligence
B. THE DOCTRINE OF ESTOPPEL
C. THE DUTY OF CARE FOR CRAs
1. The question of 'proximity'
2. The 'assumption of responsibility' rule
3. The application of the Hedley Byrne case to CRAs $\quad 7.54$
D. THE CAPARO CASE
1. The 'three-stage test' for CRAs

8. UNITED STATES

A. THE RATING AGENCIES' FIRST AMENDMENT PROTECTION IN THE UNITED STATES $\quad 8.01$

1. The presumption of being 'financial reporters' $\quad 8.11$

2. The nature of rating as commercial speech $\quad 8.20$

B. THE PROFESSIONAL LIABILITY OF CRAs UNDER THE DODD-FRANK ACT $2010 \quad 8.28$

1. The shortcomings of professional liability $\quad 8.34$

9. EUROPEAN UNION

$\begin{array}{ll}\text { A. REGULATION NO 462/2013 } & 9.01\end{array}$

1. The question of Article $35 \quad 9.04$

2. The burden of proof for the investor $\quad 9.10$

B. THE ABSENCE OF A HARMONIZED LIABILITY REGIME UNDER EU LAW 9.15

10. AUSTRALIA
A. THE BATHURST CASE
10.01
1. The fiduciary duty to investors
10.07
2. The tort claim in negligence and the statutory claim for damages
10.12
B. IMPLICATIONS OF THE AUSTRALIAN LEGISLATION FOR CRAs' LIABILITY 10.19

\section{PART IV CONCLUSIONS}

